Трифонова Мария Александровна

аспирантка кафедры социологии Российского университета дружбы народов

\section{РИСКИ КАК УГРОЗЫ: ОБЕСПЕЧЕНИЕ БЕЗОПАСНОСТИ СОВРЕМЕННОГО ОБЩЕСТВА (НА ПРИМЕРЕ РОССИИ И США)}

\begin{abstract}
Аннотация:
В статье рассматривается актуальное для современного мира понятие риска. Риски присут ствует во всех сферах общественного развития. Однако проявление той или иной угрозы для человечества на сегодняшний день достигает очень высокого уровня, что связано с развитием модернизации и научно-технического прогресса. Современный мир столкнулся с такими угрозами, как войны глобального характера, кибератаки, загрязнение окружающей среды, опасность вирусных заболеваний и m. д. Все это отчасти продукты человеческой деятельности, последствия применения и использования которых иной раз оцениваются и прогнозируются неверно. В работе проанализированы основные виды рисков главные угрозы и опасности для России и США, согласно общественному мнению. Предложень потенциальные меры борьбы с рисками, которые помогут обеспечить безопасность современного общества и уберечь его от глобальных угроз.
\end{abstract}

Ключевые слова:

риск, общество риска, риски в России, риски в США, методы борьбы, общественное мнение.
Trifonova Maria Aleksandrovna

PhD student, Department of Sociology,

Peoples' Friendship University of Russia

RISKS AS THREATS: SECURING MODERN SOCIETY (A CASE OF RUSSIA AND THE USA)
The research deals with the relevant concept of risk Any area of social development is full of risks. However, humanity is under a serious threat today because of rapid modernization and scientific and technological advances. The modern world has faced threats such as global wars, cyberattacks, environmental pollution, and dangerous virus infections. Sometimes, it is hard to predict and assess the effects of these partly manmade products. The research analyzes the main types of risks, the major threats and dangers to Russia and the United States based on public opinion. Potential risk-control measures are proposed to help secure modern society and protect it from global threats.

Прогресс общественного производства можно рассматривать в двух формах: развитие и разрушение. Общество риска - это взгляд на мир, в котором деятельность человека можно анализировать также с точки зрения положительных последствий и негативных сторон. Существует два типа переходного общества: созидательный и разрушительный [1, с. 5]. Созидательный тип общества характеризуется высокой модернизацией, несмотря на риски и опасности. Общество разрушительного типа проявляет демодернизацию. Итогом эволюции общественной системы может выступать риск и опасность; кроме того, они могут выступать продуктом осознанного конструирования. Важное значение в теории общества риска играет понятие среды обитания индивида. «Общество риска есть общество средовых вызовов и императивов» [2, с. 6] . Предугадать цену ошибки по конкретному решению является дольно сложным, а порой нереальным моментом. Поскольку мы не можем со стопроцентной вероятностью учесть все риски, мнения экспертов различаются, политические, экономические и иные решение тоже, во всем этом уже потенциально заложен риск.

Бездействие в сложных ситуациях, связанное с различного рода факторами, заставляет людей дорого расплачиваться за риск. Для этого необходимо выстраивать своевременный путь защиты.

На сегодняшний день для российского общества характерна поляризация относительно базовых ценностных ориентаций. Для одних людей приоритетом становится создание семьи, для других же главной ценностью является материальное благополучие. Люди боятся заглядывать в далекое будущее, поскольку все может измениться в любую минуту.

Новые вызовы общества риска, т. е. некие трансформацииф определенных институтов, законов, норм в условиях меняющегося общества, заставляют индивидов проявлять рефлексию.

Акторы, которые производят риски, пытаются организовать необходимый им социальный порядок, который впоследствии навязывается обществу. Риск-потребители играют по правилам 
риск-производителей. Риск-производители рассматривают общество, его территории с точки зрения ресурсного обогащения, как источника богатства. Риск-потребители же ориентированы на общество прежде всего как пространство, нужное для жизнедеятельности.

Производство рисков - довольно прибыльный бизнес, производитель получает богатство и власть, общество же стратифицируется по признаку: производители и потребители рисков. Одни индивиды получают негативное воздействие от производства рисков, другие извлекают из этого процесса положительные моменты. Так, одни страны, социальные группы и организации получают прибыль и обогащаются из производства рисков, пользуясь полученными благами, другие же подвергаются воздействию рисков. Однако У. Бэк описывает «эфффект бумеранга», который гласит, что риск настигает в конечном счете и тех, кто на нем наживался или считал себя застрахованным от всякого рода угроз [3, с. 25-31].

Риски можно рассматривать в рамках классовой схемы, только в обратном порядке: богатства находятся в верхних слоях, риски расположены на нижней ступени. Люди, обладающие высоким материальным положением, властью и образованием, могут купить безопасность и свободу от той или иной угрозы. Риски, связанные с работой (облучение, причинение вреда здоровью, отправление и др.), для работников разных профессий распределяются по-разному. Люди, живущие поблизости от промышленных заводов и других сооружений на протяжении длительного времени, получают разного рода дозу вредных и ядовитых веществ, которые содержатся в воде, воздухе или почве. Однако люди вынуждены терпеть данные условия, поскольку боятся потерять рабочее место или не имеют возможности изменить текущую ситуацию. Тот, кто обладает высоким доходом, имеет возможность избежать данного риска благодаря смене места жительства или улучшению условий проживания. Это касается и питания, и образа жизни, и образования, и т. д. «Набитый кошелек» предоставляет человеку возможность употреблять только «экологически чистые продукты», закупать питание в дорогих ресторанах или за границей. Но если возникают проблемы в поставках таких продуктов или происходит параллельное загрязнение воды, то тогда происходит уравнивание классов, несмотря на материальные различия между ними. Классовые барьеры разрушаются и в случае повышенного содержания ядовитых веществ в окружающей среде - воздухом мы дышим все. Эффективная защита в таких условиях достигается, только лишь если человек не будет есть, пить и дышать. Однако выжить ему при таких условиях просто не удастся [4, с. 23-24].

Роль науки как производителя знаний играет важную роль в общественной жизни и политике. В условиях научно-технического прогресса расширяется производство рисков, причем появляются довольно опасные его виды, которые невозможно воспринять органами чувств человека. Существование данных рисков наблюдается в виде знаний о них. Поэтому обществу необходимы специалисты в каждой области рискогенности современных технологий, а СМИ являются источником, предоставляющим нам данную информацию.

Необходимо формирование группы экспертов, обладающих весомым политическим значением, чтобы определить степень потенциальной угрозы, именно они устанавливают приемлемый уровень риска. Привилегированность группы несет и негативный момент для общества. Эксперты становятся элитой, обладающей властью и давлением на остальное население. Такая дифрференциация на экспертов и остальное население подрывает доверие к науке, поскольку информация о рисках искажается экспертами, замалчиваются многие моменты, а также отсутствуют ответы на вопросы, выдвигаемые инициативными группами. Это противостояние затрудняет принятие истинно верного решения и усугубляет текущую оценку опасных угроз. У. Бэк отмечает, что наука должна приниматься обществом как законный институт, способный принимать решения. Общество риска политически нестабильно. Уверенность в завтрашнем дне исчезает, поскольку в любую минуту может наблюдаться накал политических страстей и напряженности. Таким образом, отмечает ученый, общество может вернуться к прошлому режиму: авторитарному или даже тоталитарному.

«Риск - это возможность того, что человеческие действия или результаты его деятельности приведут к негативным или позитивным последствиям, которые воздействуют на человеческие ценности» [5, с. 13].

Риски можно разделить на две группы: чистые и спекулятивные [6, с. 118]. Чистые риски (экологические, природные, политические, транспортные и коммерческие (торговые, производственные и имущественные)) говорят о возможности получения нулевого или отрицательного результата. Спекулятивные риски (финансовые) содержат в себе возможность получения положительного или отрицательного итога.

Природно-естественные риски связаны с природными бедствиями и катаклизмами: пожарами, наводнениями, землетрясениями, песчаными бурями, снежными лавинами и т. д.; экологиче- 
ские риски связаны с политикой, проводимой государством; транспортные риски - с передвижением грузов на транспорте (автомобиль, поезд, корабль, самолет и т. д.). Коммерческие риски связаны с возможной финансовой потерей в условиях проведения какой-нибудь сделки и разделяются по структурному признаку на торговые, фринансовые, имущественные и производственные риски.

Внешние и внутренние фракторы заставляют Россию обороняться и отстаивать свое положение на мировой арене. В условиях давления со стороны конкурирующих стран (страны Европы, США, Великобритания и др.) государству необходимо принимать быстрые и решительные меры, позволяющие избегать негативных последствий для страны и ее граждан. Экономический кризис, санкции Запада, ситуация на биржевых рынках - все это отрицательно сказывается на развитии России. Глобализация достигла пика своего развития, и уже сейчас следует многое менять. Дестабилизация мировой системы породила такие глобальные риски, как: мировой фринансово-экономический кризис; падение мировой финансово-валютной системы; войны глобального характера; демографрические и социальные катастрофры.

Исходя из перечисленных рисков, можно сказать, что стратегия стран Запада и США направлена на усиление геополитического влияния и ослабление всеми возможными способами сил конкурентов. Главной целью Запада является экономическая, политическая, социальная дестабилизация России. Информационная, санкционная, политическая война в отношении России - явное тому подтверждение. Это своего рода провокация, созданная для того, чтобы втянуть Россию в серьезный конфликт и возложить на нее полную ответственность за возможные последствия. При этом в России существует довольно много внутренних проблем, их решение сдерживает внешнее давление. Это проблемы социального, экологического, экономического характера и т. д.

Для современной России и в краткосрочной перспективе ее развития можно выделить следующие виды рисков:

1) экономические и фринансовые риски (инфляция, высокий курс доллара, ухудшение условий для бизнеса из-за принятых Западом санкций, отток иностранных инвестиций, крах банковский организаций и т. д.);

2) социальные и внутриполитические риски (попытка стран извне дестабилизировать экономическую и политическую ситуацию в России);

3) геополитические и военные риски (ситуация на Ближнем Востоке и Украине);

4) риски технологического отставания (Россия существенно отстает от стран Запада по внедрению современных инновационных технологий, способствующих весомому прогрессу в стране);

5) демографрические риски (увеличение смертности и падание рождаемости, отсутствие рабочей силы и др.);

6) риски и угрозы в информационной и идеологической сфрерах (утрата контроля над СМИ и интернетом вследствие кибератак, раскол элит);

7) террористические угрозы

Чтобы предотвратить рассматриваемые нами риски, России необходимо выполнять следующие задачи:

1) проводить грамотную внешнюю политику для удержания и повышения своего геополитического влияния, выдерживая оказываемое давление со стороны стран Запада;

2) повысить экономическое развитие страны путем развития высокоинновационных технологий и своего производства;

3) действовать в рамках общенациональной идеологии;

4) развивать военно-технический потенциал.

Можно выделить следующие меры по сдерживанию и недопущению потенциальных опасностей и рисков в России (на самом деле их количество может быть довольно большим).

Геополитическая сфрера. Биполярность мировой политики ставит перед обществом возникновение новых угроз и опасностей. Для объединения усилий в отстаивании своих политических и экономических интересов мировые государства вступают в интеграционные союзы. Рассмотрим это на конкретном примере, а именно Евразийского экономического союза (ЕАЭС).

Изначально образование ЕАЭС было направлено на формирование общей экономической системы стран-участниц с целью создания особых условий по производству и распределению товаров. Однако некоторые страны-противники восприняли данный союз как потенциальную угрозу своей безопасности. Они считали, что главным фактором создания такой кооперации был мотив воссоздания СССР, что повлекло за собой массовые информационные атаки на данную организацию.

В современном мире одним из главных вопросов остается борьба за геополитическое господство. ЕАЭС выступает в роли организации, которая пытается балансировать данное противостояние, исходя из своих экономических и геополитических возможностей. 
Площадка Евразийского пространства служит хорошим фундаментом для реализации единой стратегии сотрудничества во всех общественно значимых сферах. Безусловно, на данную организацию оказывают свое негативное влияние внешние фракторы в форме провокаций «третьих стран». Также существуют внутренние противоречия по многим вопросам. И главной целью ЕАЭС должно быть их преодоление и приход к консенсусу, поскольку потенциал Евразийской интеграции очень велик. Как показывает мировая практика, в одиночку противостоять сегодняшним рискам государству довольно трудно, поэтому взаимодействие между странами в фрормате ЕАЭС является эффективной мерой. Это лишь один из примеров правильной стратегии по взаимодействию со странами-партнерами.

Экономическая сфрера. Для развития экономики необходимо добиться притока иностранных инвестиций, создать хорошие условия малому бизнесу с целью импортозамещения в условиях санкционной политики стран Запада; развивать промышленное производство и т. д.

В научно-технической сфрере следует не допускать оттока «умов» за рубеж, создавая все условия для работы в нашей стране; предотвращать выдачу поддельных дипломов о высшем образовании; формировать научно-инновационные пространства по примеру «Сколково»; поддерживать развитие науки на высоком уровне и т. д.

Экологическая сфера. Нужно разрабатывать и обновлять комплекс правил, направленных на защиту окружающей среды; сократить количество вредных выбросов в атмосферу; восстановить лесничества на всей территории; не допускать и уголовно преследовать нарушения эксплуатации на производствах и др.

Социальная сфрера. Экономический кризис, геополитическая напряженность напрямую отражаются на жизни населения. Социальная защита - важнейшее обязательство государства перед его гражданами. В условиях экономических санкций произошла трансформация экономики России. Потребовалось определенное время для адаптации к текущей ситуации и разработки ответных мер. На сегодняшний день многие проблемы удалось решить, однако еще существует большое количество неразрешенных вопросов.

Перейдем к рассмотрению текущего вопроса на примере Америки. В США существует так называемый доклад о национальной стратегии безопасности, ежегодно его предоставляет президент согласно закону от 1986 г. В нем изложена позиция США по ключевым моментам ее мировых интересов, которые являются важными с точки зрения национальной безопасности. Одним из главных постулатов данной доктрины за все время ее существования остается позиция «об особой исключительности США». Главной задачей своего правительства в 2017 г. Дональд Трамп считал «защиту страны, сохранение американской общности и безопасность американского народа» [7, с. 88]. Реализация установки требует решения следующих проблем: обеспечение безопасности территории и границ США; поиск источников угроз; безопасность в киберпространстве; защита от эпидемий; иммиграционная политика и пограничный контроль. Опасной террористической угрозой для нации является ИГИЛ (запрещена в РФ). Также, по мнению президента, необходимо бороться с преступностью (ограбления, убийства, наркобизнес). Большое количество американцев умирают от употребления наркосодержащих веществ, в частности опиума.

Угрозой безопасности являются атаки в киберпространстве, они могут привести к тому, что противник сможет получить данные военного командования, экономических операций, энергоресурсов и иных сфрер. Приоритетной мерой в отношении предотвращения данной угрозы выступает улучшение анализа ситуаций в жизненно важных областях. Важными моментами в данном документе являются рассуждения о том, что американцам необходимо уметь переносить невзгоды, а именно адаптироваться и защищаться от атак со стороны противников, природных происшествий, угроз в области экономической стабильности и демократии. Также в стратегии говорится об экономической безопасности (в 2002 г. в США произошла рецессия, это привело к повышению налогов, стоимости медицинского страхования и медикаментов, цен на образование).

Главными задачами программы Д. Трампа в 2017 г. являлось: добиться доминирования в энергетике; поощрять правильно выстроенные экономические отношения; добиться особых позиций в науке, инновациях и изобретениях. «Энергетическое доминирование - это главная позиция Америки в глобальной энергетической системе, поскольку Америка является лидирующим производителем, потребителем и новатором» [8, с. 90].

Авторы стратегии также говорят о необходимости развития новых технологий, весьма необходимых для экономического развития и ее безопасности: это нанотехнологии, искусственный интеллект, генная инженерия и т. д.

По мнению авторов стратегии, главной реальной угрозой для США остается Россия. Россия пытается воссоздать статус великой державы, повысить влияние у своих границ, ее главной целью является ослабление влияния США на мировой арене, а также разрушение всех их связей с союзниками и партнерами. На России лежит огромная ответственность за вмешательство в выборы и 
внутриполитические дела других стран, в результате чего создается нестабильная обстановка и повышается риск конфликтов. Так, США будут непременно взаимодействовать с союзниками и решать все вопросы с позиции силы. Россия и Китай пытаются перевести геополитическое влияние в свою пользу. Согласно стратегии, США необходимо развивать ядерный потенциал.

Большое внимание следует уделить «экономической дипломатии». «Экономические рычаги, включая санкции, пресечение отмывания денег и антикоррупционные меры могут стать важной частью глобальной стратегии по сдерживанию, ограничению и принуждению противника» [9, с. 91]. В документе говорится о необходимости сотрудничества США с международными организациями в рамках соблюдения общих интересов. Взаимодействие США и Европы как торговых партнеров и союзников является очень важным. алиям.

Насколько данная стратегия объективна и успешна, можно судить уже по сегодняшним ре-

Понимание мира, главных угроз и опасностей остается в сфере интересов каждого государства.

Согласно данным института Рейгана (Reagan Institute) на 2019 г., большинство американцев считают Россию своим врагом (71\%), 28 \% принявших участие в опросе - союзником. Прежде всего американцы связывают с Россией такие угрозы, как кибератаки (24 \%), поддержка стран, враждебных США (21\%), и ядерная угроза (16\%). Главной угрозой американцы также называли Китай, Северную Корею и Иран. По мнению респондентов, такой альянс, как НАТО, очень хорошо работает, и его необходимо больше фринансировать [10]. По данным ВЦИОМ на 2019 г., граждане РФ характеризуют отношения между Россией и США как «напряженные» (53 \% опрошенных), «прохладные» (20\%) и «враждебные» (13\%) [11].

Что касается ситуации в России по опасениям россиян в 2019 г., то самый главный страх большинства россиян - угроза болезней детей и родных (61 \% респондентов «Левада-центра»). На втором месте среди самых распространенных страхов - угроза войны (42\%), на третьем страх бедности (31\%). Еще $22 \%$ среди своих основных страхов назвали стихийные бедствия, 18 \% боятся лишиться накопленных сбережений, 16 \% участников опроса - потерять работу [12].

Таким образом, мы рассмотрели основные угрозы и опасности, характерные для российского и американского общества, опираясь на данные общественного мнения. Как можно видеть, существует большое количество рисков, несущих потенциальную или реальную опасность для общества. И тут очень важным моментом является ответственность отдельного индивида, группы лиц, политической элиты за те действия, которые ими совершаются. Государство различных стран должно защищать свое население от потенциальных опасностей и обеспечивать им лучшие условия жизни в стране, заботясь об экологии, геополитике, медицине, социальной сорере и т. д. Продуманная тактика действия государства служит гарантом мира, процветания и стабильности как на мировой арене, так и внутри самого государства.

Изученные нами положения об обществе риска могут служить источником информации, направленной на разработку мер по преодолению и недопущению различного рода рисков. Подходы по управлению рисками необходимо прорабатывать еще до начала наступления каких-либо опасностей, чтобы иметь возможность избежать их или же минимизировать последствия. Как известно, «эффект бумеранга» обладает уравнительным и обобщающим свойством, затрагивая не только виновника происшествия, но и вынуждает платить всех остальных.

\section{Ссылки:}

1. Яницкий О.Н. Россия как общество риска: методология анализа и контуры концепции // Общественные науки и современность. 2004. № 2. С. 5-15.

2. Там же. С. 6.

3. Бек У. Общество риска: На пути к другому модерну / пер. с нем. В. Седельника, Н. Федоровой. М., 2000. 383 с.

4. Там же. С. 23-24.

5. Акимов В.А., Лесных В.В., Радаев Н.Н. Риски в природе, техносфере, обществе и экономике / В. А. Акимов, В.В

6. Лесных, Н. Н. Радаев ; МЧС России. М., 2004. 352 с.

7. Поляков А.В. Система управления рисками (виды, классификация, уровень рисков) // Экономика и управление. 2008. № 6 (38). C. 118-121.

8. Грибин Н.П. Глобализация стратегических амбиций. Критический анализ «стратегии национальной безопасности 2017» Дональда Трампа // Международная аналитика. 2017. № 4 (22). С. 86-95.

9. Там же. С. 90.

10. Там же. C. 91.

11. Annual Reagan National Defense Survey Shows Broad Support for Peace Through Strength, American Leadership in the World : November 2019 [Электронный ресурс] // Raegan Institute. URL: https://www.reaganfoundation.org/ (дата обращения: 08.12.2019).

12. ВЦИОМ назвал главные страхи россиян: 12 ноября 2019 г. [Электронный ресурс] // BЦИOM. URL: https://www.wciom.ru/ (дата обращения: 01.12.2019). 
13. Социологи назвали главные страхи россиян: 29 октября 2019 г. [Электронный ресурс] // Левада-центр. URL: https://www.levada.ru/ (дата обращения 02.11.2019).

\section{References:}

Akimov, VA, Lesnykh, VV \& Radayev, NN 2004, Risks in Nature, Technosphere, Society, and Economy, EMERCOM of Russia, Moscow, 352 p., (in Russian).

'Annual Reagan National Defense Survey Shows Broad Support for Peace Through Strength, American Leadership in the World' 2019, Raegan Institute, November, viewed 08 December 2019, <https://www.reaganfoundation.org/>.

Beck, U, Sedelnik, V \& Fedorova, N (trans.) 2000, Risk Society: Towards a New Modernity, Moscow, 383 p., (in Russian).

Gribin, NP 2017, 'Globalization of Ambitions. A Critical Analysis of Donald Trump's National Security Strategy 2017', Mezhdunarodnaya analitika, no. 4 (22), pp. 86-95, (in Russian).

Polyakov, AV 2008, 'Risk Management System (Types, Classification, and Risk Level)', Ekonomika i upravlenie, no. 6 (38), pp. 118-121, (in Russian).

Yanitsky, ON 2004, 'Russia as a Risk Society: Analysis Methodology and an Outline of the Concept', Obshchestvennye nauki i sovremennost, no. 2, pp. 5-15, (in Russian).

Редактор: Хорева Людмила Николаевна Переводчик: Куликова Маргарита Александровна 